\author{
J. Isenegger \\ K. Nedeltchev \\ M. Arnold \\ U. Fischer \\ G. Schroth \\ L. Remonda \\ H.P. Mattle
}

\section{Reasons to withhold intra-arterial thrombolysis in clinical practice}

Received: 11 February 2005

Received in revised form: 23 July 2005

Accepted: 12 August 2005
$\mathrm{J}$. Isenegger, $\mathrm{MD} \cdot \mathrm{U}$. Fischer

Dept. of Internal Medicine

University of Bern

Bern, 3010 Bern, Switzerland

K. Nedeltchev, MD · M. Arnold, MD

H. P. Mattle $(\square)$

Dept. of Neurology

University of Bern

Inselspital, 3010 Bern, Switzerland

Tel.: +41-31/632-3332

Fax: +41-31/632-0321

E-Mail: heinrich.mattle@insel.ch

G. Schroth, MD · L. Remonda, MD

Dept. of Neuroradiology

University of Bern

Inselspital, 3010 Bern, Switzerland
Abstract Background In selected stroke centers intra-arterial thrombolysis (IAT) is used for the treatment of acute stroke patients presenting within 6 hours of symptom onset. However, data about eligibility of acute stroke patients for IAT in clinical practice are very scarce. Methods We collected prospectively data on indications advising for or against IAT of 230 consecutive stroke patients in a tertiary stroke center. Results 76 patients $(33.0 \%)$ presented within 3 hours, $69(30 \%)$ between 3 and 6 hours of symptom onset and $85(37 \%)$ later than 6 hours. Arteriography was performed in 71 patients (31\%) and IAT in 46 (20\%). In 11 patients no or only peripheral branch occlusions were seen on arteriography and therefore IAT was not performed. In 9 patients the ICA was occluded and barred IAT and in five anatomical or technical difficulties made IAT impossible. 72 patients presenting within 6 hours did not undergo arteriography and thrombolysis, mostly because of mild $(n=44)$ or rapidly improving neurological deficits $(n=13)$. Other reasons to withhold IAT were CT and/or clinical findings suggesting lacunar stroke due to small vessel occlusion $(\mathrm{n}=7)$, limiting comorbidty $(\mathrm{n}=7)$ and baseline international normalized ratio $>1.7(\mathrm{n}=1)$. Conclusions A third of the patients underwent diagnostic arteriography and one fifth received IAT. The most important reasons to withhold thrombolysis were presentation beyond the 6 hours time window and mild or rapidly improving symptoms.

Key words stroke. acute $\cdot$ stroke management . thrombolytic therapy

\section{Introduction}

Intravenous thrombolysis (IVT) with recombinant tissue plasminogen activator (rt-PA) and local intraarterial thrombolysis (IAT) using recombinant prourokinase or urokinase have been found effective for treatment of acute ischemic stroke in randomized trials $[8,18,22]$. In routine clinical practice both treatment modalities are safe and efficacious when ส guidelines are followed [7, 15, 21]. Most guidelines zecommend IVT within 3 hours of symptom onset, though a more recent metaanalysis indicates a benefit up to 4.5 hours [12]. Nevertheless, this narrow treatment window limits the number of patients eligible for IVT. In multicenter surveys $1.6 \%$ to $6.8 \%$ of patients have received IVT $[13,14,20,24]$. Individual hospitals where special referring systems for stroke patients had been created to accelerate admission, thrombolysed from $15 \%$ to $18 \%$ of their patients $[9,10]$.

The IAT trials have shown that IAT can be applied up to 6 hours after stroke onset in patients with M1 or M2 segment occlusion of the middle cerebral artery (MCA). As time is one of the main limiting factors for 
IVT, the extended time window for IAT should result in more patients amenable to thrombolysis. However, whether the extended time window for IAT, considering the technical and logistical complexity of IAT, will result in more thrombolysed patients is unknown. The purpose of this study was to analyze the number of patients undergoing IAT and the reasons to withhold it in a single tertiary care center.

\section{Methods}

\section{Stroke center and catchment area}

The Inselspital is a tertiary care center. IAT, started in 1992, is now used as the preferred stroke treatment and offered 24 hours a day. Some results and the referral practice in our hospital have been published previously $[1,3,4,16,19,25]$. Patients are referred mainly from the city area of approximately 300000 inhabitants and some selected patients from a larger region of up to 1500000 people. At the time of the study, thrombolysis for stroke was not performed in any of the community hospitals.

\section{Patient selection}

All ischemic stroke patients aged 16 to 80 years admitted from 1 July 2001, until 30 June 2002, were included in this study. Data were collected prospectively and recorded in a stroke registry. Stroke was diagnosed if symptoms or signs of a focal neurological deficit evolved rapidly and lasted longer than 24 hours. Hemorrhage was ruled out by CT or MRI.

The neurological status was assessed after admission by a neurologist using the NIHSS score [6]. Time of stroke onset was considered as the moment when the patient or a witness noted a neurological abnormality. If the symptoms were noted on awakening, stroke onset was defined as the moment the patient was last seen well. Patients were categorized into five groups depending on the time from symptom onset to admission: $<3$ hours, 3-6 hours, 6-12 hours, 12-24 hours and $>24$ hours. Patients of the two first groups underwent angiography when considered eligible for IAT [4]. All reasons for exclusion from IAT were analyzed. For patients who presented after 6 hours, the reasons for delayed admission were recorded. Outcome was assessed 3 months after the ictus by clinical examination using the modified Rankin scale (mRS) in patients who underwent arteriography or thrombolysis [23].

\section{Statistical analysis}

Statistical analysis was performed using SPSS 10 statistical software (SPSS Inc). Subgroup analyses were performed for patients admitted directly to the Inselspital and for those referred by surrounding community hospitals. The $\chi^{2}$ and the Mann-Whitney tests were used to assess different ways of referral.

\section{Results}

During the study period 230 patients aged 16 to 80 years with acute ischemic stroke were admitted (Table 1 ). The mean age was $62.2 \pm 13.8$ years. $39.6 \%$ were women. 76 patients $(33 \%)$ presented within 3 hours, 69 (30\%) from 3 to 6 hours, 37 (16\%) from 6 to 12 hours, $25(11 \%)$ from 12 to 24 hours and 23 (10\%) after 24 hours. 151 patients (66\%) were admitted directly and 79 (34\%) via community hospitals. 71 patients $(31 \%)$ underwent diagnostic arteriography and 46 (20\% of all patients; $65 \%$ of those with arteriograms) received IAT. Patients referred from community hospitals were more likely to qualify for arteriography (50\% of 79 ) and IAT (32\% of 79 ) than patients who had been admitted directly $(21 \%$ and $14 \%$ of $151 ; p<0.0001)$. The median NIHSS score of all patients was 4 (range 1 to 31 ), of those treated with IAT 14 (range 3 to 24) and of those not receiving thrombolysis 3 (range 1 to 31 ). 115 patients had a NIHSS score $\geq 4$ at admission.

Two patients (1\%) were treated within 3 hours of symptom onset with intravenous recombinant tissue plasmogen activator (rt-PA), one because of a dissected and occluded internal carotid artery that prevented intraarterial access to the occluded middle
Table 1 Demographic data, time to presentation and rates of diagnostic arteriography, IAT or IVT

\begin{tabular}{lccc}
\hline & $\begin{array}{l}\text { Direct admissions, } \\
\mathrm{n}=151(100 \%)\end{array}$ & $\begin{array}{l}\text { Referrals from } \\
\text { community hospitals, } \\
\mathrm{n}=79(100 \%)\end{array}$ & $\begin{array}{l}\text { All Patients with } \\
\text { ischemic stroke, } \\
\mathrm{n}=230(100 \%)\end{array}$ \\
\hline $\begin{array}{l}\text { Age, mean (SD), years } \\
\text { Women }\end{array}$ & $62.5(14.1)$ & $61.8(13.2)$ & $62.2(13.8)$ \\
NIHSS score, median (range) & $60(40 \%)$ & $31(39 \%)$ & $91(40 \%)$ \\
Time to presentation after symptom & $3(1$ to 31$)$ & $8(1$ to 24$)$ & $4(1$ to 31$)$ \\
$\quad$ & & \\
$\quad$ onset at the Inselspital & & $27(34 \%)$ & $76(33 \%)$ \\
$3-6$ hours & $49(33 \%)$ & $40(51 \%)$ & $69(30 \%)$ \\
$6-12$ hours & $29(19 \%)$ & $1(1 \%)$ & $37(16 \%)$ \\
$12-24$ hours & $36(24 \%)$ & $5(6 \%)$ & $25(11 \%)$ \\
$>24$ hours & $20(13 \%)$ & $6(8 \%)$ & $71(31 \%)$ \\
Immediate arteriography & $17(11 \%)$ & $39(50 \%)$ & $46(20 \%)$ \\
IAT & $32(21 \%)$ & $25(32 \%)$ & $2(1 \%)$ \\
IVT & $21(14 \%)$ & 0 & $2(1 \%)$
\end{tabular}

NIHSS score indicates National Institutes of Health Stroke Scale Score; IAT, intraarterial thrombolysis; IVT indicates intravenous thrombolysis 
cerebral artery, and the other because both neuroradiologists were busy with other interventions.

No thrombolysis followed the diagnostic arteriography in 24 patients $(10.5 \%$ of 230$)$, in 11 of them no or only peripheral branch occlusions (M3 or M4) were seen on arteriography. In one patient an atheromatous pseudoocclusion of the ICA was responsible for the patient's symptoms. He was successfully treated with PTA and stenting. In 9 patients the ICA was occluded and rendered local IAT of the intracranially occluded vessels technically impossible. One mentioned above received IVT after the arteriography within three hours of symptom onset. An additional patient with a hypoplastic vertebral artery on one side and an occluded vertebral artery on the other side could not be treated with IAT either. In two patients the time window for IAT elapsed while trying to reach the occluded intracranial vessel and in one patient arterial hypertension was not controllable.

Up to 3 hours 35 of 76 patients underwent arteriography and 19 received IAT. In the 3 to 6 hours window the numbers are 35 arteriograms in 69 patients and 26 IATs. A patient with a basilar artery occlusion was treated at 6.5 hours. One patient each treated with IAT in the groups 0-3 hours and 36 hours had a symptomatic cerebral hemorrhage $(5 \%)$.
The reasons for excluding patients presenting within 6 hours from diagnostic arteriography and thrombolysis are given in Table 2. Most frequently mild symptoms were the reasons. 44 patients $(19 \%$ of 230) had a NIHSS score $\leq 4.13$ patients $(6 \%)$ were excluded despite NIHSS score $\geq 4$ because of rapid improvement.

Reasons for delayed presentation after 6 hours are summarized in Table 3 . The most frequent reasons were stroke onset during sleep $(n=24)$, uncertain time of onset $(\mathrm{n}=28)$, and waiting and expecting symptoms to improve $(\mathrm{n}=23)$.

Clinical outcome of patients who underwent thrombolysis and of those patients who were not treated with thrombolysis after arteriography are presented in Table 4.

\section{Discussion}

Our data demonstrate that the indications for arteriography with the intention to use IAT for stroke treatment are given in approximately one of three patients. Of three patients who undergo arteriography two would probably receive IAT ultimately, i.e., approximately one of five stroke patients or $20 \%$ of all admitted.
Table 2 Reasons to withhold arteriography and thrombolysis in patients presenting within 6 hours of symptom onset
Table 3 Reasons for delayed presentation past 6 hours after symptom onset at the Inselspital

\begin{tabular}{llll}
\hline & $\begin{array}{l}\text { Number of } \\
\text { patients }\end{array}$ & $\begin{array}{l}\text { Percentage of } \\
\text { all patients } \\
\text { presenting }<6 \\
\mathrm{n}=145\end{array}$ & $\begin{array}{l}\text { Percentage of all } \\
\text { patients with } \\
\text { ischemic stroke, } \\
\mathrm{n}=230\end{array}$ \\
\hline $\begin{array}{l}\text { Mild symptoms (NIHSS score }<4, \text { no } \\
\text { isolated aphasia or hemianopsia) }\end{array}$ & 44 & $30 \%$ & $19 \%$ \\
$\begin{array}{l}\text { Rapidly improving neurological deficit } \\
\text { CT and clinical findings suggesting } \\
\text { lacunar stroke due to small vessel }\end{array}$ & 13 & $9 \%$ & $6 \%$ \\
$\quad \begin{array}{c}\text { occlusion } \\
\text { Limiting comorbidity * }\end{array}$ & 7 & $5 \%$ & $3 \%$ \\
$\begin{array}{l}\text { Baseline international normalized } \\
\text { ratio }>1.7\end{array}$ & 7 & $5 \%$ & $2 \%$ \\
\hline
\end{tabular}

* Limiting comorbidity: Metastatic cancer $n=2$, severe chronic heart failure $n=2$, severe chronic obstructive lung disease $n=1$, history of stroke with severe disability $(n=2)$

\begin{tabular}{llll}
\hline & $\begin{array}{l}\text { Number of } \\
\text { patients }\end{array}$ & $\begin{array}{l}\text { Percentage of } \\
\text { all patients with } \\
\text { ischemic stroke, } \\
\mathrm{n}=230(100 \%)\end{array}$ & $\begin{array}{l}\text { Percentage of the } \\
\text { patients presenting } \\
>6 \mathrm{~h}, \mathrm{n}=85(100 \%)\end{array}$ \\
\hline Stroke onset during sleep & 24 & $10 \%$ & $28 \%$ \\
Ignoring and waiting symptoms to improve & 23 & $10 \%$ & $27 \%$ \\
Uncertain time of stroke onset & 28 & $12 \%$ & $33 \%$ \\
Helpless and found too late & 5 & $2 \%$ & $6 \%$ \\
Delayed transfer from community hospital & 5 & $2 \%$ & $6 \%$ \\
\hline
\end{tabular}


Table 4 Clinical outcome three months after stroke in patients who underwent arteriography

\begin{tabular}{llllll}
\hline & $\begin{array}{l}\text { Time to } \\
\text { presentation }\end{array}$ & $\begin{array}{l}\text { Number of } \\
\text { patients }\end{array}$ & $\begin{array}{l}\text { Favorable } \\
\text { outcome } \\
\text { (mRS 0 - 2) }\end{array}$ & $\begin{array}{l}\text { Poor outcome } \\
\text { or dead (mRS 3 - 6) }\end{array}$ & $\begin{array}{l}\text { Symptomatic } \\
\text { hemorrhage }\end{array}$ \\
\hline Intraarterial Thrombolysis & $0-3 \mathrm{~h}$ & $19^{*}$ & $9(47 \%)$ & $9(47 \%)$ & $1(5 \%)$ \\
& $3-6 \mathrm{~h}$ & 26 & $14(54 \%)$ & $12(46 \%)$ & $1(4 \%)$ \\
Intravenous Thrombolysis & $0-3 \mathrm{~h}$ & 2 & 1 & 1 & 0 \\
No visible occlusion on arteriography & $0-3 \mathrm{~h}$ & 8 & 5 & 3 & \\
$\quad$ or peripheral branch occlusion & $3-6 \mathrm{~h}$ & $3^{*}$ & 2 & 0 & \\
Occluded internal carotid artery & $0-3 \mathrm{~h}$ & $6^{+}$ & $3^{+}$ & 3 & 2 \\
& $3-6 \mathrm{~h}$ & 3 & 1 & 2 & \\
Technical or anatomical problems & $0-6 \mathrm{~h}$ & 5 & 3 & 2 & \\
$\quad$ (no thrombolysis) & & & & 3 &
\end{tabular}

* Outcome data missing for one patient, ${ }^{+}$One patient treated with Intravenous Thrombolysis mRS indicates modified Rankin Scale score
In the first 3 hours 35 of 76 patients qualified for arteriography. If we had been practicing IVT, they all would have undergone IVT. However, after arteriography 19 patients only received IAT. Six patients had an occluded ICA that made intracranial IAT technically impossible. One of them received subsequently IVT; five did not receive active treatment. They might have possibly derived a benefit from IVT. Therefore, we have changed our policy since. When CT or MR angiography shows carotid occlusion in MCA stroke, we perform IVT or attempt mechanical recanalization [17].

Eight patients presenting within 3 hours did not show any vessel occlusion on arteriography that could have been recanalized. Five of them had a favorable outcome (mRS $\leq 2$ ), similar to $75 \%$ of our experience in a larger series [2]. How much their benefit from IVT and how big their risk of hemorrhage would have been remains speculative, because trials with direct comparisons of IVT, IAT and combined IVT/IAT have not been published to date. It is likely that advances in MR and CT imaging will help to select ideal patients for intravenous or intraarterial treatment [11].

Patients in the 3 to 6 hours time span would not have been treated with IVT. Therefore they represent the cohort that has drawn a benefit from the prolongation of the treatment window because of the intraarterial approach. Overall, the patients who received IAT in the 3 to 6 hours time span represent $11 \%$ of all admissions and $54 \%$ had a favorable outcome.

Patients with a low NIHSS score are likely to recover without any intervention. In randomized trials patients with a NIHSS score of 4 or more were included, a score indicating that some degree of disability is likely to remain. The NIHSS score at admission was $\leq 4$ in 115 patients. Of the other 115 patients with a NIHSS score $\geq 442 \%$ were treated.

The biggest obstacle to administering i.v. rt-PA to stroke patients is the narrow 3 hours treatment window. Despite substantial efforts many patients still arrive between 3 to 6 hours and thus too late for IVT [9]. For these patients IAT or IVT based on clinical findings and imaging represent worthwhile treatment that can be implemented in larger institutions. However, more than a third of all patients presented beyond 6 hours, when IAT is generally no longer an option. In a study by Barber et al. $29 \%$ of those presenting after 3 hour had recognized their symptoms but had chosen not to seek medical attention immediately [5]. In our cohort $27 \%$ of those presenting after 6 hours indicated the same reason for late presentation. Other reasons for delayed presentation or withholding thrombolysis were stroke during sleep or uncertain time of symptom onset. Future trials will show if such patients could benefit from thrombolysis or mechanical recanalization if they are selected by combined clinical and imaging criteria and not solely on the basis of time to treatment.

In conclusion, our data demonstrate that tertiary care centers with continuously available IAT can offer thrombolysis to a substantial proportion of patients. However, many patients still present too late. Therefore, further widespread efforts are needed to increase public awareness of stroke and to optimize organization of emergency services and stroke centers.

Acknowledgments and Funding We thank Pietro Ballinari, $\mathrm{PhD}$, for statistical advice. This study was supported in part by a grant of "Stiftung zur Förderung der wissenschaftlichen Forschung an der Universität Bern" 


\section{References}

1. Arnold M, Nedeltchev K, Mattle HP, Loher TJ, Stepper F, Schroth G, Brekenfeld C, Sturzenegger M, Remonda L (2003) Intra-arterial thrombolysis in 24 consecutive patients with internal carotid artery T occlusions. J Neurol Neurosurg Psychiatry 74:739-742

2. Arnold M, Nedeltchev K, Brekenfeld C, Fischer U, Remonda L, Schroth G, Mattle H (2004) Outcome of acute stroke patients without visible occlusion on early arteriography. Stroke 35:1135-1140

3. Arnold M, Nedeltchev K, Schroth G, Baumgartner RW, Remonda L, Loher TJ, Stepper F, Sturzenegger M, Schuknecht B, Mattle HP (2004) Clini$\mathrm{cal}$ and radiological predictors of recanalisation and outcome of 40 patients with acute basilar artery occlusion treated with intra-arterial thrombolysis. J Neurol Neurosurg Psychiatry 75:857-862

4. Arnold M, Schroth G, Nedeltchev K, Loher T, Remonda L, Stepper F, Sturzenegger M, Mattle HP (2002) Intraarterial thrombolysis in 100 patients with acute stroke due to middle cerebral artery occlusion. Stroke 33:18281833

5. Barber PA, Zhang J, Demchuk AM, Hill MD, Buchan AM (2001) Why are stroke patients excluded from TPA therapy? An analysis of patient eligibility. Neurology 56:1015-1020

6. Brott T, Adams HP Jr., Olinger CP, Marler JR, Barsan WG, Biller J, Spilker J, Holleran R, Eberle R, Hertzberg V (1989) Measurements of acute cerebral infarction: a clinical examination scale. Stroke 20:864-870

7. Buchan AM, Barber PA, Newcommon N, Karbalai HG, Demchuk AM, Hoyte KM, Klein GM, Feasby TE (2000) Effectiveness of t-PA in acute ischemic stroke: outcome relates to appropriateness. Neurology 54:679-684

8. Furlan A, Higashida R, Wechsler L, Gent M, Rowley H, Kase C, Pessin M, Ahuja A, Callahan F, Clark WM, Silver F, Rivera F (1999) Intra-arterial prourokinase for acute ischemic stroke. The PROACT II study: a randomized controlled trial. Prolyse in Acute Cerebral Thromboembolism. JAMA 282:2003-2011
9. Grond M, Stenzel C, Schmulling S, Rudolf J, Neveling M, Lechleuthner A, Schneweis S, Heiss WD (1998) Early intravenous thrombolysis for acute ischemic stroke in a community-based approach. Stroke 29:1544-1549

10. Grotta JC, Burgin WS, El-Mitwalli A, Long M, Campbell M, Morgenstern LB, Malkoff M, Alexandrov AV (2001) Intravenous tissue-type plasminogen activator therapy for ischemic stroke: Houston experience 1996 to 2000. Arch Neurol 58:2009-2013

11. Hacke W, Albers G, Al-Rawi Y, Bogousslavsky J, Davalos A, Eliasziw M, Fischer M, Furlan A, Kaste M, Lees KR, Soehngen M, Warach S; DIAS Study Group (2005) The Desmoteplase in Acute Ischemic Stroke Trial (DIAS): a phase II MRI-based 9-hour window acute stroke thrombolysis trial with intravenous desmoteplase. Stroke 36:66-73

12. Hacke W, Donnan G, Fieschi C, Kaste $\mathrm{M}$, von Kummer R, Broderick JP, Brott T, Frankel M, Grotta JC, Haley EC Jr, Kwiatkowski T, Levine SR, Lewandowski C, Lu M, Lyden P, Marler JR, Patel S, Tilley BC, Albers G, Bluhmki E, Wilhelm M, Hamilton S, ATLANTIS Trials Investigators; ECASS Trials Investigators, NINDS rt-PA Study Group Investigators (2004) Association of outcome with early stroke treatment: pooled analysis of ATLANTIS, ECASS, and NINDS rt-PA stroke trials. Lancet 363:768-774

13. Heuschmann PU, Berger K, Misselwitz B, Hermanek P, Leffmann C, Adelmann M, Buecker-Nott HJ, Rother J, Neundoerfer B, Kolominsky-Rabas PL (2003) Frequency of thrombolytic therapy in patients with acute ischemic stroke and the risk of in-hospital mortality: the German Stroke Registers Study Group. Stroke 34:1106-1113

14. Katzan IL, Graber TM, Furlan AJ, Sundararajan S, Sila CA, Houser G, Landis DM. Cuyahoga (2003) County Operation Stroke Speed of Emergency Department Evaluation and Compliance With National Institutes of Neurological Disorders and Stroke Time Targets. Stroke 36:6

15. Lindsberg PJ, Soinne L, Roine RO, Salonen O, Tatlisumak T, Kallela M, Happola O, Tiainen M, Haapaniemi E, Kuisma M, Kaste M (2003) Community-based thrombolytic therapy of acute ischemic stroke in Helsinki. Stroke 34:1443-1449
16. Nedeltchev K, Arnold M, Brekenfeld C, Isenegger J, Remonda L, Schroth G, Mattle HP (2003) Pre- and in-hospital delays from stroke onset to intra-arterial thrombolysis. Stroke 34:1230-1234

17. Nedeltchev K, Brekenfeld C, Remonda L, Ozdoba CH, Do D, Arnold M, Mattle HP, Schroth G. Stenting Of The Internal Carotid Artery in Acute Stroke: Preliminary Results of 25 Patients. Radiology, in press

18. Macleod MR, Davis SM, Mitchell PJ, Gerraty RP, Fitt G, Hankey GJ, StewartWynne EG, Rosen D, McNeil JJ, Bladin CF, Chambers BR, Herkes GK, Young D, Donnan GA (2005) Results of a Multicentre, Randomised Controlled Trial of Intra-Arterial Urokinase in the Treatment of Acute Posterior Circulation Ischaemic Stroke. Cerebrovasc Dis. 20(1):12-17

19. Mattle HP, Kappeler L, Arnold M, Fischer U, Nedeltchev K, Remonda L, Jakob SM, Schroth G (2005) Blood pressure and vessel recanalization in the first hours after ischemic stroke. Stroke 36:264-268

20. Reed SD, Cramer SC, Blough DK, Meyer K, Jarvik JG (2001) Treatment with tissue plasminogen activator and inpatient mortality rates for patients with ischemic stroke treated in community hospitals. Stroke 32:1832-1840

21. Schmulling S, Grond M, Rudolf J, Heiss WD (2000) One-year follow-Up in acute stroke patients treated with rtPA in clinical routine. Stroke 31:1552-1554

22. The National Institute of Neurological Disorders, Stroke rt-PA Stroke Study Group (1995) Tissue plasminogen activator for acute ischemic stroke. $\mathrm{N}$ Engl J Med 333:1581-1587

23. van Swieten JC, Koudstaal PJ, Visser MC, Schouten JH, von Gijn J (1988) Interobserver agreement for the assessment of handicap in stroke patients. Stroke 19:604-607

24. Wang DZ, Rose JA, Honings DS, Garwacki DJ, Milbrandt JC (2000) Treating acute stroke patients with intravenous tPA. The OSF stroke network experience. Stroke 31:77-81

25. Weber J, Remonda L, Mattle HP, Koerner U, Baumgartner RW, Sturzenegger M, Ozdoba C, Koerner F, Schroth G (1998) Selective intra-arterial fibrinolysis of acute central retinal artery occlusion. Stroke 29:2076-2079 